\title{
Problem narodu w pismach Stanisława Staszica
}

\author{
DOI: $10.35757 /$ CIV.2010.12.06
}

$Z$ pojęciem narodu tradycyjnie związane są dwie główne koncepcje jego rozumienia, nawzajem się przy tym wykluczające. Każda $z$ nich wskazuje na odmienny aspekt owej wspólnoty. Pierwsza koncentruje uwage na kwestii polityczno-prawnej, innymi słowy: naród w jej ujęciu to ogół obywateli danego kraju. Druga kładzie nacisk na aspekt etniczno-językowy, to znaczy uwypuklone zostaje pochodzenie i język, a także kultura danej społeczności. Źródeł pierwszego sposobu definiowania można się doszukać w Oświeceniu, zwłaszcza w latach rewolucji francuskiej i odchodzenia od koncepcji wspólnoty terytorialnej na rzecz bardziej uświadomionej wspólnoty obywatelskiej. Stąd Napoleon jako cesarz Francuzów, czyli „obywatelski”, w odróżnieniu od cesarzy „terytorialnych” - Austrii czy Rosji. Ujmowanie narodu w taki sposób cechuje głównie kraje $z$ długa tradycja demokratyczna - Francję, Anglię, Stany Zjednoczone. Zauważmy, że to rozwiązanie oznacza także bardzo silny związek narodu z państwem - to ostatnie staje się gwarantem jego istnienia. Utrata państwa pociaga za soba rozbicie więzów politycznych, stąd też obecność tej koncepcji w krajach o trwałej, stabilnej państwowości. Druga koncepcja jest nieco młodsza. Wyrasta $z$ zaprzeczenia uniwersalistycznych tradycji Wieku Świateł, jej genezy można się doszukiwać w niemieckim romantyzmie, w po-

Tomasz Matlęgiewicz - absolwent Wydziału Prawa i Administracji, a także Wydziału Historycznego Uniwersytetu Adama Mickiewicza w Poznaniu. Wykładowca na Wydziale Filologii i Dziennikarstwa oraz na Wydziale Historycznym Uniwersytetu w Archangielsku. 
szukiwaniu „źródeł” narodu, w modzie na folklor itd. Była próba odpowiedzenia sobie przez Niemców na pytanie „Czy my jesteśmy narodem?” - zrozumiałe, jeśli mieć na uwadze rozdrobnienie polityczne ówczesnej Rzeszy. Utrwaliła się potem na fali, rozkwitlych bujnie w XIX wieku, nacjonalizmów. Warto też wspomnieć o wspó1czesnych teoriach narodu, które na przykład sprowadzaja jego istnienie do swobodnego wyboru jednostki (teoria woluntarystyczna). Nietrudno ją co prawda doprowadzić do absurdu, ale $z$ drugiej strony obecnie coraz częściej mamy do czynienia $z$ osobami, które urodziły się $\mathrm{w}$ mieszanych małżeństwach i moga się poczuwać do związków z ojczyzną każdego $z$ rodziców. Pojawiają się też koncepcje „odwracajace” tradycyjny porzacek, jak na przykład teoria głosząca, że to naród jest dziełem nacjonalizmu, a nie nacjonalizm narodu $^{1}$. Dla nas, zważywszy na chronologiczne uwarunkowania problemu, istotne sa wyłącznie koncepcje tradycyjne.

Polska sytuacja była nietypowa. Kraje Zachodu - Francja i Anglia - formowały w XVIII i XIX wieku nowoczesne społeczeństwa w warunkach wspólnoty państwowej, a z kolei Niemcy dążyli do jedności na podstawie wspólnoty języka. Tymczasem Rzeczpospolita Obojga Narodów, po mniej lub bardziej udanych próbach reform, uległa trzem rozbiorom i zniknęła $z$ mapy kontynentu. W ten sposób „nie zdażyła” pójść ewentualną droga Francji lub Anglii (abstrahując od tego, czy byłoby to w ogóle możliwe), ale także nie mogła wejść na drogę niemiecka, będąca efektem wielowiekowego rozdrobnienia. Jej mieszkańcy stanęli przed dramatycznym wyborem określenia swojej tożsamości w nowej sytuacji politycznej, a co za tym idzie przyjęcia określonego sposobu rozumienia narodu. Konieczne okazało się nagle opracowanie struktury pojęciowej, terminologii, która umożliwi „odnalezienie się" w nowej rzeczywistości i określenie „kto to jest Polak?”, a także kim on jest wobec innych mieszkańców dawnej Rzeczypospolitej. Na takie wyzwanie mogły odpowiedzieć przede wszystkim elity, stąd też obecne przez 
cały wiek XIX próby zdefiniowania narodu. Spośród wielu myślicieli badajacych ten problem na szczególna uwage zasługuje Stanisław Staszic, prezes Towarzystwa Przyjaciół Nauk, któremu „Bóg powierzył rozsądek Polaków”. Tematyka narodu, określenia miejsca Polski i Polaków w stosunku do innych nacji, zajmowała ważne miejsce $\mathrm{w}$ jego dziełach. Poglądy Staszica ewoluowały wraz ze zmieniającymi się realiami, a jego działalność przypadła na czasy zaiste burzliwe. Od upadajacej Rzeczypospolitej Obojga Narodów, poprzez zabór pruski, wasalne Księstwo Warszawskie, aż do Królestwa Polskiego pozostającego w unii personalnej z Rosją. Należy przy tym podkreślić, iż interpretowanie poglądów Staszica nastręcza wielkie trudności, raczej należałoby mówić o obserwacji ich ewoluowania.

Rzeczpospolita Obojga Narodów była państwem wieloetnicznym i wielokulturowym, dlatego naturalne było dążenie do rozumienia narodu w sposób polityczno-prawny. W tym też kierunku zmierzała koncepcja narodu szlacheckiego, w myśl zasady, że słowo „Polak” oznacza szlachcica - obywatela. W praktyce przejawiało się to $\mathrm{w}$ sformułowaniach typu gente Ruthenus, natione Polonus. Mamy tu wzmiankę o pochodzeniu, a więc na przykład Rusina, ale $z$ narodowości (warto podkreślić, że nie $z$ obywatelstwa) - Polaka. $Z$ drugiej jednak strony czessto brakowało konsekwencji: nazwa państwa sugerowała bowiem istnienie dwóch narodów, ale projekt Unii Hadziackiej wspominał już o trzech. W Konstytucji 3 Maja pojawiło się sformułowanie „wraz ze stanami skonfederowanymi naród polski reprezentującymi”, a więc sugerujące istnienie tylko jednego narodu, obejmujacego cały stan szlachecki. Jednak kilka miesięcy później ten sam sejm uchwalił „Zaręczenie wzajemne Obojga Narodów", czyli mamy znowu dwa narody! Ponadto pojawia się problem owego gente Ruthenus - odnosiło się ono głównie do południowo-wschodnich ziem Korony, ale można je rozciagnąć także na południowe ziemie Wielkiego Księstwa Litewskiego. Używano co prawda określeń „Koroniarz” i „Litwin”, ale trudno jednoznacznie stwierdzić, jak dalece oba składały się na „Polaka”, 
jako że ze słowem „Polska” łączono raczej tereny Korony, a zwłaszcza Wielkopolskę i Małopolskę. Widzimy zatem rozchwianie terminologiczne, w którym ważną rolę odgrywał brak jednoznacznych kryteriów określajacych naród. Innymi słowy, mamy do czynienia ze swoistym lawirowaniem między koncepcja polityczna a etniczną, a zarazem próba poszanowania odrębności obu podmiotów federacyjnego państwa.

Brak tej jednoznaczności można zaobserwować w teoretycznych ujęciach narodu w końcu XVIII wieku. Adam Naruszewicz skłaniał się ku koncepcji narodu politycznego, ale rozumianego jako wspólnota właścicieli, a więc bez tak licznej gołoty szlacheckiej. Podobnie Hugo Kołłątaj, opowiadający się za wprowadzeniem cenzusu majatkowego jako wyznacznika praw politycznych. Ten ostatni postulował ujednolicenie nie tylko prawa, ale i języka, widząc w polszczyźnie czynnik spajający naród. Innymi słowy, sugerował stworzenie nowoczesnego państwa narodowego, co musiałoby się wiązać $z$ dokończeniem polonizacji ziem wschodnich. Wśród zwolenników modelu etniczno-językowego wyróżniał się Franciszek Salezy Jezierski („Naród jest to zgromadzenie ludzi mających jeden język"2). Dodatkową trudnościa był problem przynależności narodowej ziem utraconych w wyniku pierwszego rozbioru. Konsekwentne podtrzymywanie koncepcji polityczno-prawnej byłoby zanegowaniem ich związków z Rzeczapospolitą, która przecież jako państwo nadal istniała. Prowadziłoby do sytuacji, w której część Polaków nagle przestała nimi być. Idąc dalej - upadek Rzeczypospolitej Obojga Narodów pociagałby za soba likwidację narodu polskiego. Wyraził to Stanisław Szczęsny Potocki: „Każdy z przeszłych Polaków ojczyznę sobie wybrać powinien. Ja już jestem Ro-


którzy zatem w związku z likwidacja państwa być nimi przestali. Jednak zwiazanie narodu $z$ państwem dawało nadzieję na odtwo-

\footnotetext{
2 A. Walicki: Idea narodu w polskiej myśli oświeceniowej, Instytut Filozofii i Socjologii PAN, Warszawa 2000, s. 51.

3 List Stanisława Szczęsnego Potockiego do Seweryna Rzewuskiego, w: A. Witkowska, R. Przybylski: Romantyzm, Wydawnictwo Naukowe PWN, Warszawa 1997, s. 71.
} 
rzenie go w przyszłości, jak na przykład w Pieśni Legionów Polskich we Włoszech - „będziem Polakami”. Tak więc nie ma co prawda narodu bez państwa, ale jednak on nadal istnieje w postaci potencjalnej i utajonej. Odtworzenie lub stworzenie państwa pociagnie za soba natychmiastowe pojawienie się narodu.

Pisma Staszica powstałe w czasach Sejmu Czteroletniego (Uwagi nad życiem Jana Zamoyskiego i Przestrogi dla Polski) wskazuja na skłanianie się raczej ku koncepcji polityczno-prawnej. Wydaje się, że najbliżej mu było do Adama Naruszewicza - uważał, iż „do stanowienia praw wszyscy bez wyłączenia właściciele należą"4. Przyjąwszy takie założenie, naród można uznać za wspólnotę ludzi dysponujących określonym majątkiem, połączona posiadaniem praw publicznych. Konsekwencja tego był postulat wciagnięcia mieszczan $\mathrm{w}$ proces prawodawczy, $\mathrm{i}$ to nie jako plentipotentów $z$ głosem doradczym, jak to wprowadziła później Konstytucja 3 Maja, ale jako równoprawnych współuczestników stanowienia prawa. Nie oznacza to bynajmniej, że Staszic negował podział stanowy; przeciwnie - sugerował rozdzielenie parlamentu na dwie części: mieszczańska i szlachecką ${ }^{5}$. Uznawszy za naród wspólnotę polityczna, sugerował wprowadzenie majatkowego cenzusu wyborczego. Posiadanie bowiem określonego majątku daje pewność dbałości o państwo jako dobro wspólne, będące gwarantem statusu materialnego. Założenie to pozbawiało praw politycznych gołotę, a więc część szlachty najbardziej podatną na manipulację i klientelizm. Staszic chciał widzieć naród jako wspólnotę świadomą swoich praw i obowiąków, czyli w nowoczesny, obywatelski sposób. Nawoływał także do zniesienia podziału profesji na szlacheckie i miejskie - owej nieszczęsnej zasady, zgodnie $z$ którą szlachcic wykonujacy prace mieszczańskie mógł stracić szlachectwo ${ }^{6}$. W tym okresie nie przydawał wielkiego znaczenia kwestiom językowym czy etnicznym. Wieloetniczność Rzeczypospolitej nie wykluczała

\footnotetext{
4 S. Staszic: Uwagi nad życiem Jana Zamoyskego, w: idem: Pisma filozoficzne i społeczne, Państwowe Wydawnictwo Naukowe, Warszawa 1954, t. 1, s. 41.

5 S. Staszic: Przestrogi dla Polski, w: idem: Pisma ..., t. 1, s. 296.

6 S. Staszic: Uwagi ..., s. 156.
} 
uznania wszystkich jej mieszkańców za Polaków i nadania im praw politycznych, o ile spełnia wymagania cenzusu majątkowego. Dotyczyło to zwłaszcza patrycjatu miejskiego - miasta były bowiem częstokroć wielonarodowościowe, $z$ wyraźna przewaga na przykład elementu niemieckojęzycznego (Gdańsk, Toruń), ale poczuwającego się do więzi $z$ Rzecząpospolitą. Rozwój terytorialny państwa wiąże się przeto $z$ rozszerzeniem narodu, nie ma podziału na „nowych” i „rdzennych” mieszkańców. Możemy więc uznać, że Staszic nie uważał Rzeczypospolitej Obojga Narodów za państwo wielonarodowościowe. Zamieszkiwali je przedstawiciele jednego, choć wieloetnicznego, narodu połączonego wspólnym terytorium i porzadkiem prawnym. Kiedy dawna piastowska monarchia przekształciła się $\mathrm{w}$ federację, naród polski niejako rozszerzył się na Litwinów, Rusinów, Niemców i innych. Innymi słowy, przytoczone wyżej gente Ruthenus, natione Polonus można odnieść do myśli Staszicowej. Mieszkaniec Rzeczypospolitej, bez względu na pochodzenie, jest członkiem narodu polskiego. Staszicowa wizja narodu dawałaby Rzeczypospolitej szerokie możliwości wykorzystania swojego wielokulturowego charakteru. Państwo, odchodząc od XVII-wiecznego „katolickiego sarmatyzmu” jako wyznacznika narodu, stałoby się znów (jak w XVI wieku) atrakcyjne dla cudzoziemców. Koncepcja Staszica, zwłaszcza w aspekcie cenzusu majatkowego i praw miejskich, odpowiadała też potrzebom rodzacej się w Polsce burżuazji. Andrzej Walicki określa tę koncepcję mia-

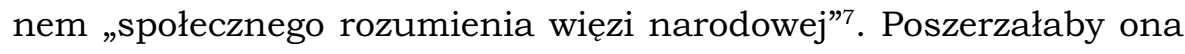
znacząco bazę narodowa, sprzegając $z$ państwem część społeczeństwa dotychczas pozbawiona roli politycznej. Porzucając przesądy stanowe, zwracał się Staszic do szlachty $z$ wezwaniem: „Róbcie z młodzieży szlacheckiej i miejskiej jeden naród!"».

Po rozbiorach Staszic nie zanegował dalszego istnienia narodu. Mimo to koncepcja polityczno-prawna była mu nadal bliska. Uważał, że trwanie narodu jest $\mathrm{w}$ znacznym stopniu uzależnio-

A. Walicki: Idea ..., s. 69.

8 S. Staszic: Przestrogi ..., s. 343. 
ne od posiadania własnego terytorium. $Z$ radościa powitał powstanie niewielkiego Księstwa Warszawskiego - „cząstka (która) odzyskała rodowitość i imię Polaka"'. Trudno określić, kim pod względem narodowościowym byli, zdaniem Staszica, mieszkańcy ziem polskich pozostajacych nadal pod zaborami. Cytowane słowa wskazuja, że status narodu nie ginie zupełnie wraz $z$ kresem państwowości, mielibyśmy bowiem wówczas do czynienia $z$ „uzyskaniem”, a nie „odzyskaniem”. Pojawia się zatem pewna ciagłość historyczna, następstwo między dawną Rzeczapospolitą Obojga Narodów a Księstwem Warszawskim. Naród może zatem przetrwać bez państwa, niejako w oczekiwaniu na jego „odtworzenie”. Mamy tu do czynienia $z$ upośledzonym, ale zawsze istnieniem narodu bez własnej państwowości. Staszic wzbogaca zatem swoja myśl o elementy bliższe etniczno-językowemu pojmowaniu narodu.

Spośród pism Staszica powstałych w czasach zaborów i Księstwa Warszawskiego najważniejszą rolę w interesujaccej nas kwestii odgrywa niewielka rozprawa zatytułowana Narodowość. W założeniu autora miała ona krótko wyjaśniać znaczenie pojęcia „narodowość", która była postrzegana jako cecha różnicująca oddzielne narody. Drugim celem było ujednolicenie terminologii, ścisłe oznaczenie treści opisywanego problemu. Punktem wyjścia rozważań Staszica jest co prawda "naród Polski”, ale następnie abstrahuje pojęcie „narodowości” i nadaje mu cechy ogólne. Stwierdzenie „naród Polski" wskazywałoby raczej na aspekt polityczny - nie cecha (naród polski), ale określenie przynależności. Stąd wynika, że państwo ma naród, a nie odwrotnie, lecz zarazem Staszic mówi o upadku, i to upadku narodu, a nie tylko państwa. Jedno wiąże się $z$ drugim, a katastrofa państwa pociaga za soba upadek narodu. Tekst rozprawy stawia wszelako pod znakiem zapytania pojmowanie narodu przez Staszica jako kategorii polityczno-prawnej. Wyróżnione zostają dwa elementy tworzace narodowość albo raczej, używając jego pojęć, dwie narodowości - przyrodnią i nabytą. Każ-

\footnotetext{
$9 \overline{P o}$ zdobyciu Krakowa przez wojska polskie w r. 1809 mowa pod posagiem Czarnieckiego $w$ Tykocinie, w: I. Chrzanowski, H. Galle, S. Krzemiński (red.): Wiek XIX. Sto lat myśli polskiej. Życiorysy, streszczenia, wyjątki, Gebethner i Wolff, Warszawa - Kraków 1906, t. 1, s. 32.
} 
da $z$ nich składa się $z$ określonych elementów, $z$ cech mniej lub bardziej charakterystycznych dla konkretnego narodu: „przyrodzona" obejmuje nazwę, ród, język, muzykę, małżeństwa między członkami danego narodu, wychowanie, poczucie sprawiedliwości, przeszłość i pamięć oraz święta. Natomiast „wtórna” - ubiory, barwy, zasiedlone terytorium i jego nazewnictwo ${ }^{10}$. Staszic nie różnicuje rangi obu tych czynników. Zarówno narodowość „przyrodzona”, jak i „wtórna” sa jednakowo wartościowe i występując łącznie, tworza narodowość w pełnym sensie tego słowa: „Lud, który $z$ tych cech jakiekolwiek nieuważnie zagubił, ten swoją narodowość naruszył"11. Wszystkie wspomniane elementy powinny być przez społeczność pielęgnowane i podtrzymywane, jeśli zamierza ona pozostać narodem. Uwage przykuwa problem małżeństw - Staszic wydaje się sugerować, że małżeństwa można zawierać tylko w obrębie jednego narodu. Taka interpretację myśli Staszica - choć trafną na pierwszy rzut oka - należy jednak uznać za błędną. W rozumieniu Staszica naród nie stanowił bowiem zamkniętej, ekskluzywnej grupy, ale właśnie grupę otwarta na nowych członków, zgodnie $z$ tradycja polityczno-prawną. Innymi słowy, małżeństwo było jednym ze sposobów umożliwiających stanie się członkiem danego narodu, wrotami dla jego nowych przedstawicieli. Odmienną rolę odgrywaja takie czynniki jak rzady, prawa, rozum, cywilizacja czy nauki jako dobro wspólne wszystkim narodom. Podlegaja one rozwojowi i ciagłym doskonalącym zmianom. Oznacza to, że przejmowanie obcych wzorów i osiagnięć $\mathrm{w}$ tych sferach nie wpływa negatywnie na naród, ale wręcz przeciwnie - dla jego rozwoju celowe i właściwe jest korzystanie $z$ dorobku innych społeczeństw. Wzajemna konkurencja i uczenie się sprzyjaja postępowi cywilizacyjnemu. Rozwijając myśl Staszica zauważamy, że również utrata niepodległości, brak własnego państwa nie przesądza o kresie istnienia narodu, jak byłoby logicznym następstwem wizji narodu politycznego. Jego dotychczasowi przedstawiciele zasililiby bowiem inny naród poli-

${ }^{\circ}$ S. Staszic: Narodowość, w: idem: Pisma ..., t. 2, s. 277-278.

${ }_{11}$ Ibidem, s. 278. 
tyczny (vide wspomniany Stanisław Szczęsny Potocki). Niezakwalifikowanie państwa do elementów współtworzacych narodowość sprawia, że naród istnieje i może się nadal rozwijać po utracie bytu państwowego. Można się pokusić o stwierdzenie, że taka sytuacja zdejmuje $z$ niego ciężar prowadzenia aktywnej polityki i pozwala na skoncentrowanie się na rozwoju kultury. Zestawienie czynników warunkujących narodowość w doktrynie Staszica sugeruje, że następowało powolne odejście od pojmowania narodu w kategoriach polityczno-prawnych na rzecz ujęcia etniczno-językowego. Staszic daleki był oczywiście od nacjonalizmu w stylu plemiennym, niemniej jednak jego dotychczasowa wizja, ukształtowana jeszcze przed rozbiorami, została uzupełniona przez nowe elementy.

Staszic podkreślał po rozbiorach range języka jako spoiwa narodu. Będąc prezesem Towarzystwa Przyjaciół Nauk, apelował do jego członków o zachowanie i rozwój języka, czego można było oczekiwać od zgromadzonej tam ówczesnej elity. Upadek języka uważał za ogromną katastrofę, zagrażająca istnieniu narodu. Uważał, że następstwem byłyby bratobójcze walki, tym straszniejsze, iż „zabijać się będą bez porozumienia sposobu, bez czucia i wiedzy nawet, że własne wytępiaja plemię"12. To wyraźne skłonienie się ku koncepcji narodu etniczno-językowego było jednak równoważone przemyśleniami zawartymi w sui generis testamencie politycznym. Opublikowane jesienia 1815 roku Ostatnie moje do współrodaków słowa zawierały stwierdzenie: „Alexander I staną obrońca praw tego Narodu, zawarował zwrot jego bytu [...] i zachował mu właściwa nadaną od samego stwórcy narodowość"13. Fragment „zwrot bytu narodu” jednoznacznie stwierdzałby, że naród po rozbiorach przestał istnieć. Niedawni Polacy rozproszyli się i dopiero przywrócenie państwa polskiego odrodziło naród. Dodajmy, że za takie Staszic uważał Królestwo Polskie, tak jak i Aleksander I był dlań legalnym polskim królem, spadkobierca

\footnotetext{
12 S. Staszic: Przemówienia w Towarzystwie Przyjaciół Nauk, w: idem: Pisma ..., t. 2, s. 279.

${ }^{13}$ S. Staszic: Ostatnie moje do współrodaków słowa, w: idem: Dzieła, t. 4, Warszawa 1816, s. 15 .
} 
dawnych monarchów. Zarazem "nadana od stwórcy narodowość" sugerowałaby odwieczność, niezmienność (przynajmniej w sferze opisywanej w Narodowości) i trwałość narodów od samego ich początku. Można się pokusić o wniosek, iż wynika $z$ niej także odporność na wynaradawianie. Wydaje się, że w myśli Staszica pojawia się tu pewna niekonsekwencja, zwłaszcza że wyżej wspominaliśmy o zagrożeniach wypływających $z$ utraty języka. On sam w jednym $z$ przemówień wyraził optymizm oraz głębokie przekonanie o trwałości narodu i języka nawet bez państwa: „[...] przesilali się nad niszczeniem naszego ojczystego języka, robiąc dzieło próżne, dzieło niepodobne, by Sławianina przemienić w Niemca"14.

$Z$ czasów Księstwa Warszawskiego pochodza pierwsze pisma wskazujace na zainteresowanie Staszica problematyka słowiańska, a także stosunkiem narodu polskiego do Słowiańszczyzny. Prowadzone przezeń badania geologiczne zaowocowały praca $O$ ziemiorództwie Karpatów, interesujacca dla nas ze względu na refleksje na temat narodów słowiańskich. Czytamy w niej na przykład o „plemionach wielkiego narodu Sławian”15. Innymi słowy, to Słowianie jako całość tworzą odrębny naród, a poszczególne grupy etniczne sa wyłącznie plemionami. Widzimy tu elementy słowianofilskie, aczkolwiek uwage zwraca też pewne rozchwianie terminologiczne pism Staszicowych. W innym fragmencie mamy bowiem: „Z szczepu Sławiańskiego narodów, Morawców, Polaków, Rusinów"16. Zasygnalizowana tutaj zaledwie klasyfikacja zostanie przez Staszica rozwinięta po Kongresie Wiedeńskim. Na razie pojawia się tylko jej zarys - narody, społeczności spojone wewnętrznie tworzą szczepy, czyli jednostki wyższego rzędu. Uwypukla to rolę czynnika etnicznego w narodzie. Zwrócmy uwagę, że termin „Morawiec" odnosi się do przedstawiciela grupy językowej nie mającej odrębnego państwa. Na równi z nim wzmiankowani sa „Rusini”,

\footnotetext{
${ }^{14}$ S. Staszic: Przemowa po ukończonym examenie $w$ Szkole Departamentowei XX. Pijarów $w$ Warszawie dnia 23 Lipca, roku 1814, w: idem: Dzieła, t. 4, s. 123.

${ }^{15} \mathrm{~S}$. Staszic: O ziemiorództwie Karpatów i innych gór i równin Polski, Wydawnictwo Geologiczne, Warszawa 1953, s. 160.

${ }^{16}$ Ibidem, s. 351.
} 
a więc Rosjanie, którzy państwo maja, a także Polacy, czyli społeczność wieloetniczna i bez państwa. Możemy przyjąć, że Staszic przywołał trzy tak zasadniczo różniące się grupy słowiańskie w celu podkreślenia ich jedności i równości. Innymi słowy, ponad oddzielnymi narodami istnieja jednostki wyższego rzędu, spojone wspólnota pochodzenia. Element etniczny odgrywa istotna rolę, ale nie na poziomie więzi narodowej, lecz wyższej - szczepowej. Podobna terminologię można zauważyć u Jana Kossakowskiego: „[Alexander I] Monarcha naypotężnieiszych na północy narodów Słowiańskich”17. „Słowiańskość” występuje tu jako czynnik łączący różne narody.

Przytoczone pisma pomijaja raczej kwestię charakteru narodowego. Staszic zatem uważał go za zmienny, nie określony raz na zawsze. Wynikało $z$ tego optymistyczne przeświadczenie o możliwości kształtowania i doskonalenia charakteru narodowego, podlegającego ewolucji. Dzięki właściwej edukacji i odpowiedniemu wychowaniu można zmodyfikować jego niekorzystne elementy. Zauważmy, że dzięki temu naród stawał się wspólnotą dynamiczną, którą można rozwijać nie tylko ilościowo, ale przede wszystkim jakościowo, przez dobrze dobrana oświatę. Staszic nawiąuje tu do twierdzenia, że „Takie będa Rzeczypospolite, jakie ich młodzieży chowanie" ${ }^{18}$. Piękny przejaw oświeceniowej wiary w dobroczynną i skuteczną działalność edukacji.

Problem definiowania narodu, konflikt koncepcji polityczno-prawnej $z$ etniczno-językową towarzyszyły myśli polskiej przez wiek XIX i znaczna część wieku XX. Były to kwestie, które musieli rozwiązać przedstawiciele wieloetnicznego państwa oraz ich potomkowie podzieleni między ościenne potęgi. Dotyczyło to również terytorialnego zasięgu narodu polskiego - czy naród ogranicza się do ziem etnicznych, czy też obejmuje całość dawnej Rzeczypospo-

\footnotetext{
${ }^{17}$ Rzut oka na literature czeska i zwiazek języków Słowiańskich. Rzecz napisana przez Jana Kossakowskiego, Biskupa Wileńskiego, członka Towarzystwa Przyjaciół Nauk, czytana na posiedzeniu publicznem, Dnia 5 Grudnia R. 1803, w: Roczniki Towarzystwa Warszawskiego Przyjaciół Nauk, t. 3, Warszawa 1804, s. 33.

${ }_{18}$ S. Staszic: Uwagi..., s. 11.
} 
litej. Był to żmudny proces formowania się koncepcji nowoczesnej wspólnoty w nietypowych warunkach, gdy świadomość rozdrobnienia między sąsiadami splatała się ze wspomnieniami dawnej potęgi. Staszic lawiruje między dwiema skrajnymi koncepcjami, co przywodzi go efekcie do wizji narodu, która nie daje się jednoznacznie zakwalifikować do żadnego $z$ modeli. Jego doktryna ewoluuje wraz $z$ płynną sytuacja polityczną. Może się wydawać nie do końca spójna, co jest skutkiem działania gwałtownie zmieniających się okoliczności, w których powstawała. Dla współczesnych była jednak jak najbardziej całościowa i kompletna, łącząc $\mathrm{w}$ sobie najistotniejsze elementy obu głównych modeli. Postulat uczestnictwa w życiu publicznym, ścisłego zwiazku $z$ państwem (także w Królestwie Polskim) sąsiaduje w niej $z$ uwzględnieniem znaczenia języka jako czynnika cementującego naród. Pamiętajmy, że w wieku XVIII język polski był w istocie językiem całej Rzeczypospolitej - zarówno Korony, jak i Litwy - szlachta ziem wschodnich uległa już przedtem daleko idacej polonizacji. Staszic do narodu polskiego zaliczał wszystkich mieszkańców Rzeczypospolitej Obojga Narodów, niezależnie od ich pochodzenia etnicznego. Już po 1815 roku wspominał o „piętnastomilionowym narodzie Polaków”19. Społeczność tę łączył nie tylko porządek polityczny, jako że już dwie dekady minęły od upadku państwa, ale przede wszystkim wspólny język ułatwiający przetrwanie w warunkach zaborów.

Oprócz określenia pojęcia „naród” Staszic zajmował się też, jak wyżej wspomniano, relacjami między narodem polskim a reszta Słowian. Szczególna wage miała ta kwestia po utworzeniu Królestwa Polskiego, splecionego unia personalna $z$ Rosją. Współistnienie dwóch tak odmiennych państw pod jednym berłem musiało oczywiście zainteresować Staszica. Zarazem chodziło o znalezienie modus vivendi ze zwycięskim sassiadem i zajęcie pozycji $\mathrm{w}$ odniesieniu do nowej władzy. Zainteresowanie problemem słowiańskim i relacjami w obrębie całej grupy narodów było zatem jak

${ }^{19}$ S. Staszic: Myśli o równowadze politycznej w Europie, w: idem: Pisma ..., t. 2, s. 302. 
najbardziej właściwe. W rezultacie ukształtowała się spójna wizja polityczna, $z$ jasną struktura pojęciową, której istotnym elementem był program o cechach wyraźnie słowianofilskich. Wygłaszane przez Staszica uroczyste mowy dawały tylko sugestie jego koncepcji narodu i planów politycznych. W przemówieniach nie majacych charakteru naukowego pojawiały się różnorodne, niekonsekwenthe określenia, na przykład „niezmierny Sławianinów ród” ${ }^{20}$, „Ród Słowian [...] wielki naród Sławian"21, podkreślające wspólnotowość łączącą Słowian. Nie możemy jednoznacznie stwierdzić, czy mówiąc o „narodzie”, Staszic miał na myśli Polaków, Rosjan, czy też w ogóle Słowian. Kategoria nazywana wcześniej „szczepem” występuje jako „ród”, a więc wspólnota pochodzenia. Pojęcie „szczep” może być już $z$ kolei interpretowane jako podkreślenie więzi politycznej. Tak czy inaczej mamy zarysowana bliskość obu narodów połączonych unia personalna. W Hymnie, pochodzacym $z$ tego samego okresu, Alojzy Feliński używał nieco innego nazewnictwa. Mówiac o wspólnocie Polaków i Rosjan, określa ich mianem ludów - „połaczył z soba dwa braterskie ludy”.

W rozprawie Myśli o równowadze politycznej $w$ Europie Staszic przedstawia rozbudowany program polityczny o zabarwieniu słowianofilskim czy wręcz panslawistycznym. Dla nas ważna jest jednak nie tyle jego treść, ile terminologia odnosząca się do kwestii narodu. Poszczególne zbiorowości układaja się w strukturę o kształcie piramidy: „Pięć jest znanych plemion na ziemi [...]. Plemię europejskie składa się $z$ pokolenia Gaulolatynów, $z$ pokolenia Teutonów, $z$ pokolenia Sławian. Pokolenie każde składa się $z$ narodów. Narody składaja się z rodzin"22. Przedstawiony zatem został układ jasny i zrozumiały - od rodziny, poprzez naród, pokolenie, plemię, aż po ludzkość w całości. Zbiorowości nazwane

\footnotetext{
${ }^{20}$ Mowa deputacji Towarzystwa Przyjaciół Nauk do cara Aleksandra I z 24 listopada 1815 r. Por. E. Kołodziejczyk: Słowianofilstwo Warszawskiego Towarzystwa Przyjaciół Nauk (18001832), „Świat Słowiański” 1909, rocznik 58, nr 9, s. 207.

${ }^{21}$ Zdanie sprawy o pracach naukowych TKWPN [...], w: Roczniki Towarzystwa Królestwa Warszawskiego Przyjaciół Nauk, t. 19, Warszawa 1827, s. 6.

22 S. Staszic: Myśli..., s. 306-307.
} 
przez Staszica „pokoleniami” to nic innego jak ludy romańskie, germańskie i słowiańskie. Uprzednio określał je raczej mianem „szczepów”, ale w Myślach... obie nazwy używane sa zamiennie. Sporadycznie użyte zostały też sformułowania „ród sławiański” albo „naród Sławian” ${ }^{23}$. Nie zmienia to jednak faktu, że generalnie rzecz ujmując, Staszic stosował już konsekwentnie określona terminologię. Jako "narody” określani byli na przykład Polacy i Rosjanie, zaś w odniesieniu do większych zbiorowości używał terminów „pokolenie” albo „szczep”. Ten ostatni utrwalił się w nauce i w większości opracowań dotyczacych myśli politycznej Staszica pojawia się właśnie określenie „szczep”.

Jak widzimy, po Kongresie Wiedeńskim w myśli Staszica występuje rozbudowana, spójna terminologia, która wyjaśnia kwestie rozumienia i nazewnictwa narodu oraz zbiorowości połaczonych więzia ponadnarodowa. Stworzony został dzięki temu aparat pojęciowy umożliwiający jednostce samookreślenie w stosunku do konkretnej zbiorowości, w zależności od tego, która kategoria (naród, szczep itd.) byłaby potraktowana jako punkt odniesienia. Niezwykle istotna kwestię relacji między narodem i szczepem Staszic rozstrzygnął jednoznacznie na korzyść szerszej zbiorowości, przyznając „bezwzględną wyższość, stanowiącym wieczne niezmienne podłoże dziejów, szczepom nad czasowemi tworami historii państwami i narodami”24. Innymi słowy, utrata państwowości nie jest dla społeczności narodowej zupełną katastrofa. Narody upadłego państwa pozostają bowiem nadal członkami ważniejszej zbiorowości, rzeczywistego podmiotu dziejów - szczepu. Staszic proponował „zmianę perspektywy" $z$ narodowej na szczepowa. Było to jednak dalekie od renegacji w stylu Stanisława Szczęsnego Potockiego. Prezes Towarzystwa Przyjaciół Nauk widział we współdziałaniu Polaków i Rosjan wielką szansę historyczną. A stąd już droga wiodła do zrealizo-

\footnotetext{
${ }^{23}$ Ibidem, s. 307, 313.

${ }^{24}$ Z. Klarnerówna: Słowianofilstwo $w$ literaturze polskiej lat 1800 do 1848, Kasa im. Józefa Mianowskiego Instytutu Popierania Nauki, Warszawa 1926, s. 58.
} 
wania koncepcji „polsko-rosyjskie państwo słowiańskie przeciwko Niemcom"25 oraz nadziei na odbudowanie Polski u boku Rosji.

Problem definicji narodu i jego samookreślenia zajmuje znaczące miejsce w myśli Stanisława Staszica. Autorytet, którym się cieszył u współczesnych, funkcja wieloletniego prezesa Towarzystwa Przyjaciół Nauk, przedstawiciela najściślejszej elity epoki, sprawiały, że jego głos znaczył bardzo wiele. Dlatego też liczono się $z$ jego opinią, określaniem wspólnoty narodowej, a także programem politycznym, konstruowanym dla współczesnych i przyszłych pokoleń. Działalność pisarska Staszica przypadła na okoliczności nietypowe, nie tyle nowe, ile przede wszystkim stale i gwałtownie się zmieniajace - próby reform, rozbiory, Księstwo Warszawskie, Królestwo Polskie. Doktryna Staszica rozwijała się powoli, wciąż zmieniała i ewoluowała, niekiedy bywała niekonsekwentna. Ujmowanie pewnych kwestii zwiazanych $z$ definiowaniem narodu oraz stosowana terminologia ulegały ciagłym przemianom. Ale i epoka, w której żył, była nad wyraz dynamiczna i niestabilna. W tym właśnie możemy szukać przyczyn wahań i niekonsekwencji, które sa obecne w jego pismach. Dlatego uspokojenie, jakie obiecywał naszemu kontynentowi Kongres Wiedeński umożliwiło pokazanie spójnej koncepcji. Przedstawiona wtedy została idea słowiańska, a zarazem jasno określone pojęcie narodu oraz jego miejsce w historii i strukturze grup społecznych. W połączeniu z potężnym sąsiadem, w jedności narodu polskiego ze Słowiańszczyzna, w zmianie perspektywy z partykularnej na szersza widział Staszic wielka szansę na odegranie znaczącej roli w dziejach, głoszac: „Spajajmy się z Rosja i oświecajmy się, bierzmy od niej potęgę, ona niech bierze od nas oświecenie"26.

$\overline{{ }^{25} \text { E. Woroniecki: Słowianofilstwo Królestwa Kongresowego, „Świat Słowiański”, 1910, nr 8, }}$ s. 78 .

${ }^{26}$ K. Koźmian: Pamiętniki, Ossolineum, Wrocław 1972, t. 2, s. 196-197. 